\title{
Posiedzenie Rady Europejskiej w dniach 27-28 czerwca 2013 r. w Brukseli. Konkluzje
}

W kontekście slabych krótkoterminowych prognoz gospodarczych bezrobocie osób mlodych osiagnęlo w niektórych państwach czlonkowskich niespotykane wcześniej poziomy, co pociagnęto za soba bardzo wysokie koszty ludzkie i spoleczne. Należy pilnie podjać działania w tym zakresie.

Rada Europejska uzgodnita dzisiaj kompleksowe podejście do zwalczania bezrobocia wśród osób młodych w oparciu o następujace konkretne działania: przyspieszenie realizacji Inicjatywy na rzecz zatrudnienia ludzi mlodych i koncentracja środków w ramach tej inicjatywy na wstępnym etapie; przyspieszenie wdrażania gwarancji dla mlodzieży; większa mobilność mlodzieży i zwiększone zaangażowanie partnerów społecznych. Rada Europejska omówiła również sposoby na pobudzenie inwestycji i poprawę dostępu do kredytów. Wezwata do uruchomienia europejskich zasobów, w tym zasobów EBI; oraz zainicjowała nowy , plan inwestycji” w celu wsparcia MŚP i pobudzenia finansowania gospodarki.

Poprawia się stabilność finansowa, jednak UE i jej państwa członkowskie muszq podjać dalsze dzialania, by Europa w pelni powrócila na ścieżkę trwalego wzrostu gospodarczego i zatrudnienia. Zdrowe finanse publiczne i polityki na rzecz trwałego wzrostu i zatrudnienia to elementy wzajemnie się wzmacniające. Jednocześnie na wszystkich szczeblach konieczne sq bardziej zdecydowane wysilki na rzecz kontynuowania reform strukturalnych oraz stymulowania konkurencyjności i zatrudnienia. W tym kontekście Rada Europejska zatwierdziła zalecenia dla poszczególnych krajów majace ukierunkowywać polityki i budżety państw czlonkowskich, zamykajac tym samym europejski semestr 2013.

Rada Europejska odniosla się również do postępów na drodze do unii bankowej, która ma podstawowe znaczenie dla stabilności finansowej i sprawnego funkcjonowania UGW I wreszcie, Rada Europejska określita kolejne kroki w kontekście wzmacniania struktury UGW i wezwata do kontynuowania prac we wszystkich tych kwestiach $w$ okresie poprzedzajacym jej grudniowe posiedzenie.

Rada Europejska serdecznie powitała Chorwacje jako czlonka Unii Europejskiej od 1 lipca 2013 r. Zlożyla również Łotwie wyrazy uznania w zwiazku z faktem, że kraj ten wypetnit zapisane $w$ Traktacie kryteria konwergencji, co pozwoli mu przyjać euro $z$ dniem 1 stycznia $2014 r$.

Rada Europejska zatwierdzila konkluzje i zalecenia Rady dotyczqce rozszerzenia oraz procesu stabilizacji i stowarzyszenia.

\section{ZATRUDNIENIE MLODZIEŻY}

1. Zważywszy na niedopuszczalnie wysoką liczbę młodych Europejczyków, którzy pozostają bez pracy, walka $z$ bezrobociem jest szczególnym i pilnym celem. Trzeba skupić wszystkie wysiłki wokół wspólnego celu, jakim jest sprawienie, by młode oso- 
by niekształcące się, niepracujące ani nieszkolące się wróciły do pracy lub do kształcenia czy szkolenia w ciagu czterech miesięcy, zgodnie z zaleceniem Rady w sprawie gwarancji dla młodzieży. W oparciu o komunikat Komisji w sprawie zatrudnienia młodzieży należy bezzwłocznie podjąć zdecydowane działania zarówno na szczeblu krajowym, jak i unijnym.

2. UE uruchomi wszystkie dostępne instrumenty na rzecz wsparcia zatrudnienia młodzieży. Rada Europejska uzgodniła kompleksowe podejście w oparciu o następujące konkretne działania:

a) przy wdrażaniu funduszy strukturalnych przedmiotem szczególnej uwagi będzie kwestia zatrudnienia młodzieży, m.in. w stosownych przypadkach niewykorzystane środki finansowe zostaną przegrupowane. Komisja i państwa członkowskie wykorzystają wszystkie możliwości, jakie daje Europejski Fundusz Społeczny (EFS) - jedno z najważniejszych narzędzi finansowych na szczeblu UE, które służy temu celowi, także poprzez wsparcie dla tworzenia nowych miejsc pracy dla młodych pracowników. W stosownych przypadkach, państwa członkowskie poprawią swoje zdolności administracyjne, z wykorzystaniem większej pomocy technicznej ze strony Komisji i zastosowaniem najlepszych praktyk;

b) zostaną podjęte wszelkie działania przygotowawcze niezbędne do tego, by Inicjatywa na rzecz zatrudnienia ludzi młodych była do stycznia $2014 \mathrm{r}$. w pełni gotowa do realizacji; umożliwi to dokonanie pierwszych wypłat środków na rzecz beneficjentów w regionach UE, w których stopa bezrobocia wśród młodzieży przekracza $25 \%{ }^{1}$. Aby Inicjatywa na rzecz zatrudnienia ludzi młodych mogła w pełni odgrywać swoją rolę, przyznana na jej rzecz kwota 6 mld EUR powinna zostać wypłacona w ciagu pierwszych dwóch lat okresu objętego kolejnymi wieloletnimi ramami finansowymi ${ }^{2}$. Ponadto pozostawione do dyspozycji marginesy poniżej pułapów wieloletnich ram finansowych na lata 2014-2017 zostaną wykorzystane do utworzenia „ogólnego marginesu na zobowiązania” przeznaczonego na finansowanie w szczególności środków służących walce z bezrobociem osób młodych. Państwa członkowskie będące odbiorcami środków w ramach Inicjatywy na rzecz zatrudnienia ludzi młodych powinny przed końcem bieżącego roku przyjąć plan zwalczania bezrobocia osób młodych, w tym poprzez realizację gwarancji dla młodzieży. Zachęca się inne państwa członkowskie, by w 2014 r. przyjęły podobne plany. W $2016 \mathrm{r}$. Komisja przedstawi sprawozdanie na temat wdrażania gwarancji dla młodzieży oraz działania Inicjatywy na rzecz zatrudnienia ludzi młodych;

c) EBI będzie przyczyniać się do zwalczania bezrobocia osób młodych za pomocą jego inicjatywy „Praca dla młodych” (Jobs for Youth) i programu „Inwestycje w umiejętności", które powinny zostać niezwłocznie wdrożone;

d) podjęte zostaną nowe wysiłki w celu wspierania mobilności młodych osób poszukujących pracy, również poprzez wzmocnienie programu „Twoja pierwsza praca

1 Zważywszy na to, że bezrobocie młodzieży w Słowenii wzrosło w $2012 \mathrm{r}$. o ponad 30\%, region wschodniej Slowenii, gdzie bezrobocie mlodzieży w 2012 r. przekraczało $20 \%$, również skorzysta ze środków w ramach Inicjatywy na rzecz zatrudnienia ludzi młodych.

${ }^{2}$ Nie będzie to miało negatywnego skutku na cele określone przez Radę Europejską w maju 2013 r. odnośnie do polityki energetycznej. 
z EURES-em". Zachęca się państwa członkowskie do tego, by wykorzystały część swoich alokacji z EFS na wspieranie programów mobilności transgranicznej. Program „Erasmus +”, który także promuje transgraniczne szkolenia zawodowe, musi być w pełni gotowy do realizacji od stycznia 2014 r. Szczególnie ważne jest porozumienie między Parlamentem Europejskim a Radą w sprawie uznawania kwalifikacji zawodowych. Należy pilnie przeanalizować wnioski Komisji prowadzące do utworzenia sieci publicznych służb zatrudnienia. Konieczne są dalsze prace, w szczególności w odniesieniu do wniosku dotyczącego zachowania uprawnień do dodatkowych emerytur, który ma zostać przyjęty w trakcie obecnej kadencji parlamentarnej;

e) wspierane będzie wysokiej jakości przyuczanie do zawodu i uczenie się poprzez praktykę, w szczególności za pomocą europejskiego sojuszu na rzecz przygotowania zawodowego, który ma zostać zainicjowany w lipcu. Na początku 2014 r. należy wprowadzić ramy jakości dla staży;

f) partnerzy społeczni muszą być w pełni włączeni w te działania i muszą w nich aktywnie uczestniczyć. Rada Europejska z zadowoleniem przyjmuje „Ramy działania na rzecz zatrudnienia młodzieży”, uzgodnione przez partnerów społecznych 11 czerwca $2013 \mathrm{r}$.

3. Na szczeblu krajowym państwa członkowskie, do których należy większość kompetencji związanych z zatrudnieniem, powinny kontynuować realizację reform. Podejmują one również środki w celu unowocześnienia systemów kształcenia i szkolenia zawodowego, zacieśnienia współpracy między sektorem edukacji a przedsiębiorstwami, aby ułatwić przechodzenie od kształcenia do zatrudnienia, sprawniejszej integracji młodych ludzi o niskich kwalifikacjach na rynku pracy, zajęcia się kwestią niedopasowania umiejętności oraz w celu promowania przyuczania do zawodu i praktyk zawodowych w kluczowych sektorach gospodarki, a także wspierania przedsiębiorczości i nowych przedsiębiorstw. Niektóre państwa członkowskie już przedstawily ambitne plany wsparcia zatrudnienia młodzieży. Konieczne sąjednak dalsze działania. W szczególności państwa członkowskie, w których stopa bezrobocia ludzi młodych jest wysoka, powinny zintensyfikować aktywne środki rynku pracy. Należy zwracać należytą uwagę na udział w rynku pracy grup młodych ludzi w trudnej sytuacji, którzy muszą stawić czoła konkretnym wyzwaniom. Rada Europejska uznaje kompetencje państw członkowskich w tej dziedzinie, przypomniała jednak, jak ważne jest przesunięcie obciążenia podatkowego $z$ pracy na inne obszary $-m$.in. poprzez zmniejszenie, w stosownych przypadkach, składek na ubezpieczenie społeczne - jako sposób zwiększania szans na zatrudnienie oraz stymulowania tworzenia miejsc pracy i pobudzania konkurencyjności. Rada Europejska wezwała do intensywniejszej wymiany najlepszych praktyk krajowych; w tym kontekście z zadowoleniem odnotowała zbliżającą się konferencję w Berlinie.

\section{WZROST GOSPODARCZY, KONKURENCYJNOŚĆ I ZATRUDNIENIE}

\section{Europejski semestr}

4. Po przeprowadzeniu dogłębnej wymiany poglądów, Rada Europejska zakończyła europejski semestr 2013, zatwierdzając zasadniczo zalecenia dla poszczególnych krajów. Państwa członkowskie odzwierciedlą teraz te zalecenia w swoich najbliższych 
decyzjach dotyczących budżetu, reform strukturalnych oraz polityki zatrudnienia i polityki społecznej; jednocześnie będą one propagować pełną krajową odpowiedzialność w tym zakresie i będą nadal prowadzić dialog społeczny. Rada i Komisja będą uważnie monitorować realizację tych decyzji. Rada będzie regularnie omawiać i oceniać sytuację gospodarczą w Europie.

5. Propagowanie wzrostu gospodarczego i konsolidacji budżetowej to elementy wzajemnie się wzmacniające. Zdrowe finanse publiczne są nieodzowne, by organy publiczne mogły zachować zdolność do wspierania trwałego wzrostu gospodarczego i zatrudnienia. W tym kontekście Rada Europejska z zadowoleniem odnotowuje, że w stosunku do kilku państw członkowskich uchylona została procedura nadmiernego deficytu; z satysfakcją odnotowuje również wysiłki podejmowane przez te państwa członkowskie, od których oczekuje się osiagnięcia celów budżetowych. Przypomina o możliwościach, jakie dają istniejące unijne ramy budżetowe, by równoważyć potrzeby w zakresie efektywnych inwestycji publicznych z celami dyscypliny budżetowej w ramach funkcji zapobiegawczej paktu stabilności i wzrostu. W przypadku niektórych państw członkowskich tempo konsolidacji budżetowej zostało dostosowane odpowiednio do warunków ekonomicznych, zgodnie z tym, co przewidują unijne ramy budżetowe. Jednocześnie państwa członkowskie powinny przyspieszyć swoje reformy strukturalne. Wzmocni to działania służące przywróceniu unijnej gospodarce równowagi, pomoże w odzyskaniu konkurencyjności i zajęciu się społecznymi skutkami kryzysu.

\section{Nowy plan inwestycji dla Europy}

6. W obecnej sytuacji gospodarczej kapitalne znaczenie ma przywrócenie normalnego kredytowania gospodarki i ułatwianie finansowania inwestycji. $Z$ racji znaczenia, jakie MŚP mają dla gospodarki, zwłaszcza w odniesieniu do tworzenia miejsc pracy, środki wspierające finansowanie MŚP będą miały charakter priorytetowy. Jest to szczególnie ważne w krajach, w których odnotowuje się wysokie bezrobocie osób młodych i w których niezbędne są nowe inwestycje w celu promowania wzrostu gospodarczego i zatrudnienia. Ważne jest także wspieranie przedsiębiorczości i samozatrudnienia. Rada Europejska uzgodniła w związku z tym zainicjowanie nowego „Planu inwestycji”.

7. Rada Europejska $z$ zadowoleniem przyjęła porozumienie osiagnięte $w$ sprawie wieloletnich ram finansowych UE na najbliższych siedem lat. Podziękowała negocjatorom z Parlamentu Europejskiego, Rady i Komisji za ich pracę i niestrudzone wysiłki, które pozwoliły wypracować dziś porozumienie. Wieloletnie ramy finansowe odegrają kluczową rolę we wspieraniu gospodarki, będąc katalizatorem wzrostu gospodarczego i zatrudnienia w całej Europie oraz zwielokrotniając efekt inwestycji w produkcję i inwestycji w kapitał ludzki. Rada Europejska wezwała do szybkiego i formalnego przyjęcia rozporządzenia $\mathrm{w}$ sprawie wieloletnich ram finansowych i związanego $\mathrm{z}$ nimi porozumienia międzyinstytucjonalnego. W związku z powyższym Rada Europejska $\mathrm{z}$ aprobatą odnotowała także porozumienia osiagnięte w sprawie nowych programów, takich jak Erasmus, COSME, „Horyzont 2020” oraz Program na rzecz zatrudnienia i innowacji społecznych. Rada Europejska podkreśliła znaczenie, jakie ma:

a) przyjęcie przed końcem roku poszczególnych programów UE, które wspierają realizację strategii „Europa 2020”; 
b) współpraca państw członkowskich z Komisją w celu jak najszybszego zawarcia umów o partnerstwie i programów operacyjnych;

c) szybkie wdrożenie funduszy strukturalnych, jak również programu na rzecz konkurencyjności przedsiębiorstw oraz MŚP (COSME) i programu na rzecz badań naukowych i innowacji („Horyzont 2020”), które są szczególnie istotne w kontekście wspierania MŚP;

d) przyspieszenie realizacji fazy pilotażowej obligacji projektowych. Komisja zamierza przedstawić swoją ocenę przed końcem $2013 \mathrm{r}$.

8. Rada Europejska z zadowoleniem przyjęła sprawozdanie Komisji i EBI na temat finansowania gospodarki. Uzgodniła następujące środki i z aprobatą przyjęła fakt, że Komisja i EBI zamierzają wprowadzić je w trybie priorytetowym, a także - przed posiedzeniem Rady Europejskiej w październiku 2013 r. - przedłożyć kompleksowe sprawozdanie $\mathrm{z}$ ich realizacji określające cele ilościowe, instrumenty i harmonogram:

a) zintensyfikowanie wysiłków EBI na rzecz wsparcia kredytowania gospodarki poprzez pełne wykorzystanie niedawnego zwiększenia kapitału EBI o 10 mld euro. Rada Europejska wzywa EBI, by zrealizował swój plan zwiększenia prowadzonej przezeń działalności kredytowej w UE o co najmniej 40\% w latach 2013-2015. W tym celu EBI już określił nowe możliwości kredytowania na kwotę przekraczającą 150 mld euro w dziedzinie kilku kluczowych priorytetów, takich jak innowacje i umiejętności, dostęp MŚP do finansowania, efektywne gospodarowanie zasobami i infrastruktura strategiczna;

b) rozwój wspólnych instrumentów finansowych opartych na podziale ryzyka między Komisją Europejską a EBI, aby w jak największym stopniu wykorzystać inwestycje sektora prywatnego i rynków kapitałowych w MŚP. Inicjatywy te powinny zapewnić zwiększenie wolumenu nowych pożyczek dla MŚP w całej UE, z poszanowaniem zasad dotyczących dobrej kondycji finansowej i przejrzystości, jak również pułapów określonych $w$ wieloletnich ramach finansowych. Rada, w porozumieniu z Komisją i EBI, niezwłocznie określi parametry niezbędne do opracowania takich instrumentów współfinansowanych z funduszy strukturalnych, w celu uzyskania znaczących efektów dźwigni. Należy poczynić odpowiednie przygotowania, aby umożliwić rozpoczęcie funkcjonowania tych instrumentów w styczniu 2014 r.;

c) zwiększenie zdolności EFI w dziedzinie wsparcia jakości kredytowej;

d) stopniowe rozszerzanie istniejących w EBI programów finansowania handlu w celu wspierania działalności MŚP w całej Unii, zwłaszcza w krajach objętych programami;

e) zacieśnienie współpracy między krajowymi bankami rozwoju a EBI w celu zwiększenia możliwości wspólnego prowadzenia akcji kredytowej oraz wymiany najlepszych praktyk;

f) wypracowywanie - w ścisłej współpracy z państwami członkowskimi - alternatywnych źródeł finansowania.

\section{Wdrażanie Paktu na rzecz wzrostu gospodarczego i zatrudnienia}

9. Rok temu Rada Europejska uzgodniła Pakt na rzecz wzrostu gospodarczego i zatrudnienia - pakiet szybko działających środków prowzrostowych, na które prze- 
znaczono środki w kwocie $120 \mathrm{mld}$ euro. Poczyniono znaczące postępy w realizacji tych środków, a niektóre $z$ nich już przynoszą rezultaty, niezbędne są jednak dalsze wysiłki w tym zakresie. Instytucje UE i państwa członkowskie powinny dołożyć wszelkich starań, by zapewnić szybkie wdrożenie wszystkich elementów określonych w pakcie, zgodnie z poprzednimi konkluzjami Rady Europejskiej, w szczególności w odniesieniu do jednolitego rynku, innowacji, agendy cyfrowej, usług, energii i podatków. W grudniu 2013 r. Rada Europejska oczekuje na zaktualizowane sprawozdanie z postępu prac dotyczących ww. paktu, w oparciu o regularną analizę prowadzoną przez Radę.

10. Zgodnie z ustaleniami z marca br. Rada Europejska będzie uważnie monitorować realizację wytycznych, które przedstawia w celu pobudzenia wzrostu gospodarczego i promowania konkurencyjności, zwłaszcza poprzez regularne organizowanie dyskusji tematycznych. W tym kontekście Rada Europejska przeprowadziła pierwszą wymianę poglądów na temat dwóch kluczowych zagadnień:

a) zasadniczego znaczenia, jakie ma mocna europejska baza przemysłowa jako jeden z podstawowych elementów składających się na unijną agendę wzrostu gospodarczego i konkurencyjności. Rada Europejska zaapelowała o szerokie, horyzontalne i spójne podejście do nowoczesnej europejskiej polityki przemysłowej towarzyszącej przemianie strukturalnej i odnowie gospodarczej. Pozytywnie odniosła się do przygotowanego przez Komisję Planu działania na rzecz konkurencyjnego i zrównoważonego przemysłu stalowego. Z myślą o posiedzeniu Rady Europejskiej w lutym 2014 r. oczekuje dalszych informacji od Komisji zgodnie z konkluzjami Rady Europejskiej z marca i maja 2013 r. Kolejna prezydencja jest proszona o kontynuowanie prac przygotowawczych na forum Rady;

b) przywołując swoje konkluzje z marca 2013 r., Rada Europejska z zadowoleniem przyjęła komunikat Komisji na temat dziesięciu regulacji stanowiących największe obciążenie, który stanowi wstępny wkład w prace. Oczekuje, że przed swoim posiedzeniem w październiku 2013 r. otrzyma szczegółowy program prac zawierający dalsze, a w stosownych przypadkach - nowe konkretne wnioski służące zmniejszeniu ogólnego obciążenia regulacyjnego i pobudzeniu konkurencyjności, przy stałym uwzględnieniu potrzeby zapewnienia właściwej ochrony konsumentów i pracowników. Wezwała do dalszych działań prowadzących do zwiększenia skuteczności i spójności regulacji unijnych i krajowych oraz ich uproszczenia. Powróci do tych kwestii w świetle wspomnianych wniosków.

Z myślą o dyskusjach tematycznych, które zostaną przeprowadzone na posiedzeniu w październiku 2013 r. i które mają nadać nowy impuls w zakresie innowacji, jednolitego rynku cyfrowego i usług, Rada Europejska zwróciła się do Komisji, by przed tym posiedzeniem przedstawiła sprawozdanie dotyczące wzajemnej oceny w odniesieniu do dyrektywy usługowej oraz na temat licencji w Europie.

11. Przypominając o roli, jaką w kontekście pobudzania wzrostu gospodarczego i zatrudnienia ma do odegrania handel, Rada Europejska z zadowoleniem przyjęla rozpoczęcie negocjacji w sprawie transatlantyckiego partnerstwa handlowo-inwestycyjnego ze Stanami Zjednoczonymi. 


\section{UKOŃCZENIE TWORZENIA UNII GOSPODARCZEJ I WALUTOWEJ}

12. Od momentu przedstawienia $\mathrm{w}$ grudniu ubieglego roku sprawozdania $\mathrm{pt.}$ „W kierunku faktycznej unii gospodarczej i walutowej”, postępują prace dotyczące czterech podstawowych elementów mających wzmocnić strukturę UGW. Konkretnym nowym krokom w kierunku wzmocnienia zarządzania gospodarczego będą musiały towarzyszyć dalsze działania na rzecz zwiększenia demokratycznej legitymacji i rozliczalności na szczeblu, na którym decyzje są podejmowane i wdrażane. Proces ten będzie przebiegał w oparciu o unijne ramy instytucjonalne, z pełnym poszanowaniem integralności jednolitego rynku; jednocześnie państwom członkowskim UE zapewnione zostaną równe warunki działania, także dzięki właściwej równowadze między państwami członkowskimi pochodzenia a przyjmującymi państwami członkowskimi. Proces ten będzie otwarty i przejrzysty względem państw członkowskich, które nie używają wspólnej waluty.

13. W krótkiej perspektywie kluczowym priorytetem jest ukończenie tworzenia unii bankowej zgodnie z konkluzjami Rady z grudnia 2012 r. i marca 2013 r. Ma to podstawowe znaczenie dla zapewnienia stabilności finansowej, zmniejszenia fragmentacji finansowej i przywrócenia normalnego kredytowania gospodarki. Rada Europejska przypomniała, że należy bezwzględnie przerwać błędne koło, w jakim znalazły się banki i rządy, i zwróciła uwagę na następujące elementy:

a) nowe przepisy dotyczące wymogów kapitałowych dla banków (rozporządzenie w sprawie wymogów kapitałowych/dyrektywa w sprawie wymogów kapitałowych) oraz nowy jednolity mechanizm nadzorczy odegrają bardzo istotną rolę w zapewnianiu stabilności sektora bankowego;

b) w okresie przechodzenia do jednolitego mechanizmu nadzorczego zostanie przeprowadzona ocena bilansów obejmująca ocenę jakości aktywów, a następnie test warunków skrajnych. W tym kontekście państwa członkowskie uczestniczące w jednolitym mechanizmie nadzorczym dokonaja - przed ukończeniem stosownych działań - wszelkich odpowiednich ustaleń, w tym ustanowią krajowe mechanizmy ochronne:

c) Eurogrupa uzgodniła najważniejsze cechy ram operacyjnych służących bezpośredniemu dokapitalizowywaniu banków przez Europejski Mechanizm Stabilności (EMS). Należy kontynuować prace, aby - w chwili ustanowienia skutecznego jednolitego mechanizmu nadzorczego - Europejski Mechanizm Stabilności miał, w drodze zwykłej decyzji, możliwość bezpośredniego dokapitalizowywania banków;

d) Rada Europejska z zadowoleniem przyjęła porozumienie osiagnięte w Radzie w sprawie projektu dyrektywy ustanawiającej ramy naprawy oraz restrukturyzacji i uporządkowanej likwidacji banków i zwróciła się do Rady i Parlamentu o rozpoczęcie negocjacji, których celem będzie przyjęcie przedmiotowej dyrektywy przed końcem roku. Wezwała również do przyjęcia przed końcem roku wniosku dotyczącego systemu gwarantowania depozytów;

e) w pełni skuteczny jednolity mechanizm nadzorczy wymaga jednolitego mechanizmu restrukturyzacji i uporządkowanej likwidacji dla banków objętych jednolitym mechanizmem nadzorczym. Rada Europejska oczekuje wniosku Komisji ustanawiającego jednolity mechanizm restrukturyzacji i uporządkowanej likwidacji z myślą o wypra- 
cowaniu porozumienia w Radzie przed końcem roku, tak by można było ten mechanizm przyjać przed końcem obecnej kadencji Parlamentu. Latem 2013 r. Komisja zamierza przyjąć zmienione zasady pomocy państwa w odniesieniu do sektora finansowego, z myślą o zapewnieniu równych warunków w kontekście decyzji dotyczących restrukturyzacji i uporządkowanej likwidacji obejmujących wsparcie publiczne.

14. Należy kontynuować prace nad wszystkimi elementami wzmocnionej UGW, jako że są one ściśle ze sobą powiązane:

a) trzeba wprowadzić skuteczniejsze ramy koordynowania polityk gospodarczych, zgodnie z art. 11 traktatu o stabilności, koordynacji i zarządzaniu oraz zasadą pomocniczości. W nawiązaniu do swojego komunikatu z 20 marca Komisja zamierza przedstawić jesienią wniosek dotyczący koordynacji istotnych reform gospodarczych w trybie ex-ante;

b) pomimo zbieżnych stanowisk w kwestii kluczowych zasad stanowiących podstawę koncepcji wzajemnie uzgodnionych umów i powiązanych z tym mechanizmów solidarności, w nadchodzących miesiącach niezbędne są dalsze prace $\mathrm{w}$ tych kwestiach, w szczególności w oparciu o zapowiadany komunikat Komisji w sprawie koordynacji polityki gospodarczej:

c) należy wzmocnić społeczny wymiar UGW. Na początek, istotne znaczenie ma lepsze monitorowanie i uwzględnianie sytuacji na rynku społecznym i rynku pracy w ramach UGW, zwłaszcza poprzez wykorzystanie stosownych wskaźników społecznych i stosownych wskaźników zatrudnienia w ramach europejskiego semestru. Ważne jest także zapewnienie lepszej koordynacji polityki zatrudnienia i polityki społecznej, $\mathrm{z}$ pełnym poszanowaniem kompetencji krajowych. Podstawowe znaczenie ma ponadto rola partnerów społecznych i dialogu społecznego, również na szczeblu krajowym. Komisja wkrótce przedstawi komunikat na temat społecznego wymiaru UGW.

15. Po przeprowadzeniu szczegółowych konsultacji z państwami członkowskimi Rada Europejska powróci do wszystkich tych kwestii. W październiku 2013 r. przyjrzy się w szczególności wskaźnikom i obszarom polityki, które należy uwzględnić w ramach wzmocnionej koordynacji polityki gospodarczej oraz społecznemu wymiarowi UGW. Dyskusja będzie kontynuowana w grudniu 2013 r., w celu podjęcia decyzji co do tych kwestii, w szczególności najważniejszych elementów ustaleń umownych i powiązanych mechanizmów solidarności. W przypadku wszystkich krajów nieużywających jednej waluty wszelkie tego rodzaju działania byłyby prowadzone na zasadzie dobrowolności i we wszystkich aspektach byłyby w pełni zgodne z zasadami jednolitego rynku.

16. Rada Europejska omówiła wniosek Łotwy o przyjęcie euro. Pogratulowała Łotwie osiągnięcia konwergencji dzięki jej solidnej polityce gospodarczej, budżetowej i finansowej oraz z zadowoleniem przyjęła spełnienie przez Łotwę wszystkich zawartych w Traktacie kryteriów konwergencji. Z aprobatą odniosła się do propozycji Komisji, by Łotwa przyjęła euro z dniem 1 stycznia 2014 r.

\section{POZOSTALE KWESTIE}

17. Rada Europejska wyraziła współczucie osobom poszkodowanym przez katastrofalne powodzie, które dotknęły w tym miesiącu Europę Środkową. Należy uruchomić stosowne zasoby finansowe (np. Fundusz Solidarności, fundusze strukturalne, 
Fundusz Spójności), aby w jak największym stopniu wesprzeć działania na rzecz doraźnej pomocy i odbudowy, jak również przyszłe działania zapobiegawcze, w regionach i państwach członkowskich, które najbardziej ucierpiały. Rada Europejska zwróciła się do Komisji o podjęcie szybkich i konstruktywnych działań w odpowiedzi na wnioski przedstawione przez poszkodowane państwa członkowskie, aby zapewnić możliwość niezwłocznego uruchomienia wsparcia z unijnych środków finansowych przeznaczonego dla regionów i państw członkowskich, które najbardziej ucierpiały.

18. W lutym 2013 r. Rada Europejska uznała szczególny wpływ kryzysu gospodarczego na pewne państwa członkowskie w strefie euro, który miał bezpośrednie skutki dla poziomu ich dobrobytu. Aby zaradzić tej sytuacji, dokonano pewnych dodatkowych alokacji z funduszy strukturalnych. W tamtym czasie decyzja dotycząca programu pomocy makroekonomicznej dla Cypru nie została jeszcze podjęta. Tymczasem rząd Cypru zwrócił się z wnioskiem o dodatkową pomoc. Rada Europejska zaapelowała do Parlamentu Europejskiego i Rady, by przeanalizowały możliwości, jakie dają elementy elastyczności zawarte w wieloletnich ramach finansowych, w tym instrument elastyczności, by zaradzić szczególnie trudnej sytuacji Cypru w kontekście rocznej procedury budżetowej.

19. W kwestii rozszerzenia Rada Europejska zatwierdziła konkluzje i zalecenia Rady z 25 czerwca 2013 r. Postanowiła rozpocząć negocjacje akcesyjne z Serbią. Pierwsza konferencja międzyrządowa odbędzie się nie później niż w styczniu 2014 r. Przed tą konferencją Rada przyjmie ramy negocjacyjne, a Rada Europejska zatwierdzi je na sesji, podczas której zwyczajowo omawiane są kwestie rozszerzenia.

20. Przyjęte zostały decyzje upoważniające do rozpoczęcia negocjacji w sprawie Układu o stabilizacji i stowarzyszeniu między Unią Europejską a Kosowem¹.

21. Na swoim posiedzeniu w czerwcu 2014 r. Rada Europejska przeprowadzi dyskusję służącą zdefiniowaniu strategicznych wytycznych planowania prawodawczego i operacyjnego w przestrzeni wolności, bezpieczeństwa i sprawiedliwości (na mocy art. 68 TFUE). W ramach przygotowań do tego posiedzenia kolejne prezydencje są proszone o rozpoczęcie procesu refleksji w Radzie. Komisja jest proszona o przedstawienie informacji istotnych $\mathrm{z}$ punktu widzenia tego procesu.

\section{DOKUMENTY ZATWIERDZONE PRZEZ RADĘ EUROPEJSKĄ}

- Sprawozdanie Rady z 25 czerwca 2013 r., dotyczące zaleceń dla poszczególnych krajów na 2013 r.

- Konkluzje przyjęte przez Radę 25 czerwca 2013 r. w sprawie rozszerzenia.

- Konkluzje przyjęte przez Radę 28 maja 2013 r. w sprawie rocznego sprawozdania na temat unijnej oficjalnej pomocy rozwojowej.

- Konkluzje przyjęte przez Radę 25 czerwca 2013 r. w sprawie nadrzędnego planu działania na okres po $2015 \mathrm{r}$.

- Plan działania dotyczący realizacji strategii morskiej na rzecz obszaru Oceanu Atlantyckiego, zatwierdzony przez Radę 25 czerwea 2013 r.

Użycie tej nazwy nie wplywa na stanowiska w sprawie statusu Kosowa i jest zgodne z rezolucją Rady Bezpieczeństwa ONZ 1244 oraz z opinią Międzynarodowego Trybunału Sprawiedliwości w sprawie Deklaracji niepodległości Kosowa. 